\title{
加速器駆動コンパクト中性子源の産業・医療への利用
}

\author{
福嶋 喜章 ${ }^{1}$, 熊田 博明 ${ }^{2}$, 佐藤 馨 ${ }^{3}$, 田中 浩基 ${ }^{4}$, 清水 裕彦 5 \\ ${ }^{1}$ (公財) 特殊無機材料研究所 ( $=982-0252$ 仙台市太白区茂庭台2-6-8) \\ 2筑波大学 医学医療系 ( ₹305-8575 茨城県つくば市天王台1-1-1) \\ ${ }^{3} \mathrm{JFE}$ テクリサーチ (株) ( ₹210-0855 川崎市川崎区南渡田町1-1) \\ 4 京都大学 複合原子力科学研究所 ( $~=590-0494$ 大阪府泉南郡熊取町朝代西2丁目) \\ 5 名古屋大学大学院理学研究科 素粒子宇宙物理学専攻 ( T464-8602 名古屋市千種区不老町)
}

\section{Applications of Accelerator-driven Compact Neutron Sources}

\author{
Yoshiaki FUKUSHIMA, ${ }^{1}$ Hiroaki KUMADA, ${ }^{2}$ Kaoru SATO,${ }^{3}$ \\ Hiroki TANAKA, ${ }^{4}$ and Hirohiko SHIMIZU ${ }^{5}$ \\ ${ }^{1}$ Advanced Institute of Materials Science, 2-6-8 Moniwadai Taihaku-ku Sendai 982-0252 \\ ${ }^{2}$ Faculty of Medicine, University of Tsukuba, 1-1-1 Tennodai Tsukuba Ibaraki 305-8575 \\ ${ }^{3}$ JFE Techno-Research Corporation, 1-1 Minamiwatarida-cho, Kawasaki 210-0855 \\ ${ }^{4}$ Institute for Integrated Radiation and Nuclear Science, Kyoto University, \\ 2 Asashiro-Nishi, Kumatori-cho, Sennan-gun, Osaka 590-0494 \\ ${ }^{5}$ Graduate School of Science Division of Particle and Astrophysical Sciences, Nagoya University, \\ Furo-cho, Chikusa-ku, Nagoya 464-8602
}

(Received July 25, 2018)

\begin{abstract}
Recent topics of applications of compact neutron sources and expected possibilities of a laser-driven neutron source for industrial and medical uses are discussed. The laser-driven neutron would be suitable for neutron resonance absorption imaging because of its point source with narrow pulsed width. A boron nutron capture therapy (BNCT) using an accelerator have been confirmed as an efficacious radiation treatment for cancers. Compact neutron facilities and those at J-PARC are useful tools for researches and development in industries such as steel, tire rubber and automobile companies. Although the laser driven one is also expected to be applied for these applications, collaborative works of laser and neutron scientists and medical and industrial sites should be necessary.
\end{abstract}

Key Words: Compact neutron source, Neutron resonance absorption imaging, BNCT, Steel industry, Industrial application

1.はじめに

大強度陽子加速器施設 $(\mathrm{J}-\mathrm{PARC})$ が本格的に稼働を始 め, 中性子産業利用推進協議会の先駆的活動等により, 産業界による中性子利用が大きく広がっている。一方, J-PARCや大型原子炉を用いなくても，回折実験や中性 子イメージングなどは小型中性子源でも必要な情報が得 られることは, 東北大学核理研LINAC, 北大LINACあ るいは京大原子炉などで示されていた. しかし, 理化学 研究所において開発された理研小型中性子源システム (RANS) は小型中性子源が, 産業界にとって使い勝手の 良い解析手段の一つとなることを再認識させた。また， ホウ素中性子捕捉療法 (BNCT) などの医療分野への応用 の可能性も小型発生源利用で，その実現性が期待出来る 状況となっている.
レーザー駆動も小型加速器とともに，産学の区別なく 材料分析あるいは医療のための中性子発生源として期待 されている。ささらに, レーザー駆動では発生源が小さく でき中性パルス幅が狭い特徴を有する。これらの特徴を 活かし，他の中性子源にはないレーザー駆動ならではの 利用の可能性を示唆する結果もJ-PARCや北大加速器で 得られている.

2.レーザー駆動独自の特徵を活かした応用 〜共鳴吸収イメージング〜

中性子の透過像による構造物の内部を観測する手法は 材料の欠陥観察や機械部品の設計に広く活用されてい る. 加速器等を駆動源とする小型中性子の開発が望まれ ており，理化学研究所において開発された理研小型中性 
子源システム $(\mathrm{RANS})^{1}{ }^{1}$ が注目されている. RANSで実施 されている中性子イメージングによる社会インフラ点検 への応用 ${ }^{2}$ については，本特集号にも紹介されているの で本報での重複は避ける。 また，インフラへの応用以外

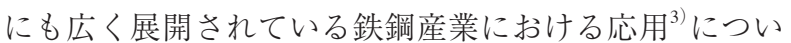
ては，本報4節で紹介したい。レーザーを駆動源とする 小型中性子源はレーザースポットと同程度のポイント ソースである特徵を活かすことにより，イメージング装 置そのものの小型化あるいは高い空間分解能が実現する 可能性を持つ.

レーザー駆動では中性子源のポイント化に加えて，パ ルス幅が非常に狭くできる。中性子と原子核との共鳴現 象を飛行時間 (T-O-F) 法により観測する手法との組合せ により新たな展開が期待される。共鳴現象による中性子 の吸収，共鳴吸収のエネルギーは原子核種固有であり核 種の断面積と密度が吸収係数と定量的に関連付けられ る。パルス中性子源を利用した中性子イメージングで は中性子共鳴分光法 (Neutron Resonance Absorption Spectroscopy $)^{4)}$ との組合せによる共鳴吸収イメージング5)に より，物質中の元素(原子核種)分布定量が可能となる。 すなわち, Fig. 1(a)に示したように，パルス中性子の通 り道に置かれた試料の中性子透過度を二次元中性子検出 器で測定し, さらに中性子源から検出器までの飛行時間 を分析することにより得られる共鳴吸収スペクトルから 元素の種類と組成が求められることになる。この共鳴吸 収に伴い発生する $\gamma$ 線を検出するFig. 1(b) の即発 $\gamma$ 型で も元素分布や組成を観察することが出来る. 即発 $\gamma$ 型で 分布を得るためには中性子ビームを走査する必要があ り, 二次元検出器と中性子飛行時間分析の組合せによる 透過型が効率的と言える。この吸収エネルギーは中性子 反応断面積を収録した評価済核データーライブラリ JENDL-4 ${ }^{6}$ を参照し求められる。

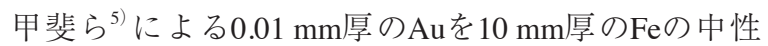
子の透過率を比較した測定例をFig. 2 に示す。通常の中 性子ラジオグラフィに利用される $100 \mathrm{meV}$ 以下の熱中性 子に対し， $0.01 \mathrm{~mm}$ 厚のAuに対して厚さが千倍のFeの透 過率が圧倒的に大きい。 これは, $\mathrm{Fe}$ 中の $\mathrm{Au}$ の検出は不 可能に近いことを意味している。しかし， $\mathrm{Au} の$ 共鳴吸

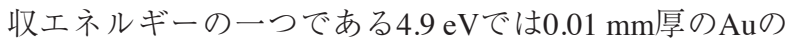
透過率は10 mmのFeのそれより大きく，このエネルギー に注目して解析すればFe中の $\mathrm{Au} の$ 分布が強調されて観

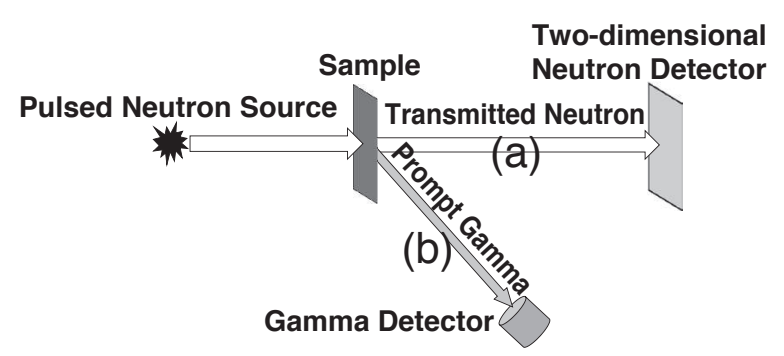

Fig. 1 Conceptual diagram of (a) Neutron Resonance Transmission Imaging ${ }^{5)}$ and (b) Neutron Resonance Capture Imaging.

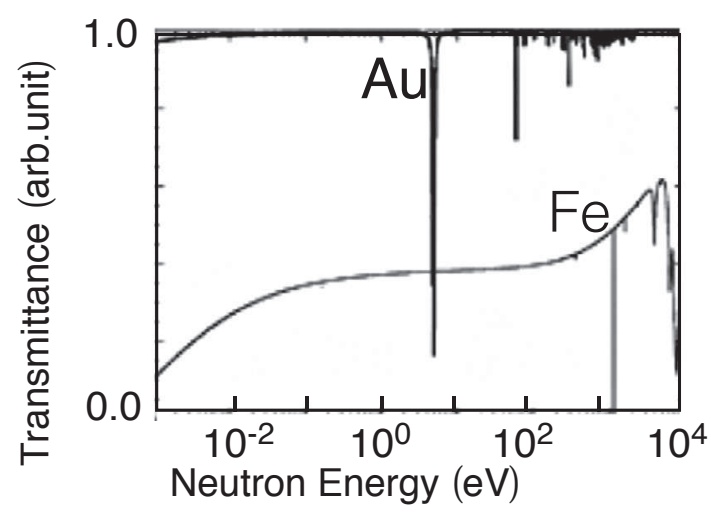

Fig. 2 Energy Dependence of Neutrons for Fe $\left(10 \mathrm{~mm}^{\mathrm{t}}\right)$ and $\mathrm{Au}\left(0.01 \mathrm{~mm}^{\mathrm{t}}\right)^{5)}$

測できることを示している，水素を除いて大半の元素は 共鳴を持つため，そのエネルギーを選ぶことにより元素 の感度を高めた中性子イメージングが可能となる。主要 な共鳴吸収エネルギーは本特集号冒頭に示してある。 レーザー駆動で得られる点光源中性子を利用することに

より特徴ある実験系の構築が期待される.

現在J-PARCのパルス中性子源を用い，1-30 eV程度の 比較的高エネルギー領域の中性子を用いた予備実験が実 施されて抢り，約 $100 \mathrm{~mm} \times 100 \mathrm{~mm} \times 15 \mathrm{mmt} の \mathrm{Li}$ 二次電 池陽極の $10^{2}-10^{3} \mathrm{eV}$ に共鳴吸収を持つ $\mathrm{Mn}$ や Coなどの二 次元分布を約 $150 \mu \mathrm{m}$ 程度の分解能で可視化できること が確認されている7).さらに，本特集号冒頭の解説の図 に示されているように，比較的高エネルギーに共鳴吸収 を持つ元素が多くある。中性子減速材の影響が無い，あ るいは少ない条件でレーザー駆動の点光源と短いパルス 幅を活かした実験も視野に入れることができる。しか し, Fig. 2 の例に示したように共鳴吸収は特徵的な吸収 のほかに高エネルギー領域に多くの吸収を持つ。そのた め，共存元素の存在とそれらの共鳴吸収スペクトルを考 慮に入れた注意深い解析を必要とする。したがって，共 鳴吸収に伴う $\gamma$ 線の発生を検出する即発 $\gamma$ 線型Neutron Resonance Capture Analysis (NRCA) も同時に実施し共存 元素の同時検出ができることが望ましい実験系となる. また，高エネルギー中性子は飛行速度も速いため高時間 分解能の測定系の開発が必須となる. 中性子検出器周辺 の $\gamma$ 線遮蔽と併せて, 非常に挑戦的な研究開発が今後必 要となるであろう.

\section{3. 小型中性子源に適した応用〜BNCTガン治療〜}

ホウ素中性子補足療法 (Boron Neutron Capture Therapy) はFig. 3 に示したように，熱中性子に対して大きな反応 断面積を持つホウ素 $\left({ }^{10} \mathrm{~B}\right)$ を含有する化合物を予めガン 細胞に集積させ，中性子との反応により生成する ${ }^{4} \mathrm{He}$ 原 子核 $\left(\alpha\right.$ 線) と ${ }^{7} \mathrm{Li}$ 原子核によりガン細胞を破壊する手法で あり，新しい放射線治療の一つとして期待されている. この手法ではガン細胞近傍の健全な細胞への放射線の影 響を最小限に出来るため, 脳腫瘍など従来の放射線治療 では困難な部位の治療に適している。1936年にケンブ 


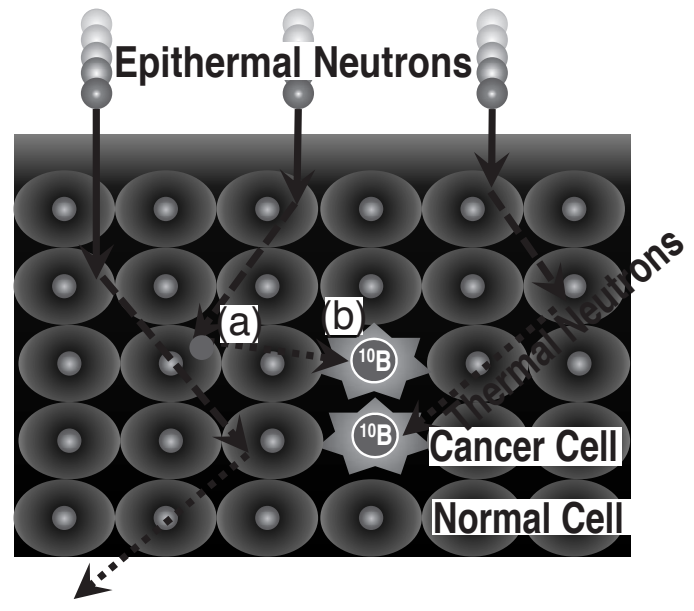

Fig. 3 Conceptual sketch of boron neutron capture therapy. (a) Incident epithermal neutrons are modified to thermal neutrons, and (b) The thermal neutrons are react with ${ }^{10} \mathrm{~B}$ at the cancer cell.

リッジ大学のJ. Chadwick教授により提案された この手 法は1950年代から本格的な検討 ${ }^{9}$ が開始された。わが国 でも同時期に東海村の実験用原子炉JRR-1を用いて検討 された。しかし，中性子に伴う $\gamma$ 線による影響や熱中性 子の強度不足，ガン細胞に選択的に集積する薬剤などの 課題のために満足できる治験が得られなかった。その 後, 1970年代以降腫瘍への集積度の高いホウ素化合物 ${ }^{10)}$ が発見され，さらに $\gamma$ 線の少ない高品質で $6 \times 10^{9} \mathrm{n} /\left(\mathrm{cm}^{2} \cdot \mathrm{s}\right)$ 程度の熱中性子束の施設が京大原子炉 $($ KUR $)$ に整備さ れるなどにより著しく進展した。

治療に適した約 $20 \mathrm{meV}$ 程度のエネルギーの熱中性子 は生体内の血液などの主要構成元素である水素による散 乱のため, 体内のガン細胞に到達する間に減衰する という課題があった。 しかし, Fig. 3 に示したように, $0.5 \mathrm{eV}$ から $40 \mathrm{keV}$ 熱外中性子を照射することにより， 皮膚からガン細胞までの生体物質が減速材の役割をする ため標的細胞位置で十分な熱中性子量が得られることが 明らかにされ, 京大原子炉や日本原子力研究機構の実験 用原子炉を用いて脳, 皮膚, 肺, 肝臓などへの多くの治 験が得られるようになっだ11

ここまでは実験用原子炉での試みが中心であったが， ホウ素薬剂注入や患部への集積の確認のための陽電子放 射断層撮影, Positron Emission Tomography (PET) あるい はその他医療設備の整備されている。中核病院内あるい はその近隣で薬事登録可能な医療機器として設置可能な 小型中性子源が望まれていた。この要望に応えるため, 陽電子加速器などとBNCTに最適な標的物質を組み合わ せた設備の開発が京都大学原子炉研究所, 住友重機工 業, 筑波大学 ${ }^{12}$ などで行われた。京都大学原子炉研究所 と住友重機工業との共同開発では, サイクロトロンによ り $30 \mathrm{MeV}, 1 \mathrm{~mA}$ に加速した高エネルギー陽子を $5.5 \mathrm{~mm}$ 厚のベリリウム標的に入射して得られた高エネルギー中 性子を, アルミニウムとフッ化カルシウムを組合せた減 速材によりFig. 4 に示したようなBNCTに適したエネル ギー分布を持つ熱外中性子を発生させることに成功し

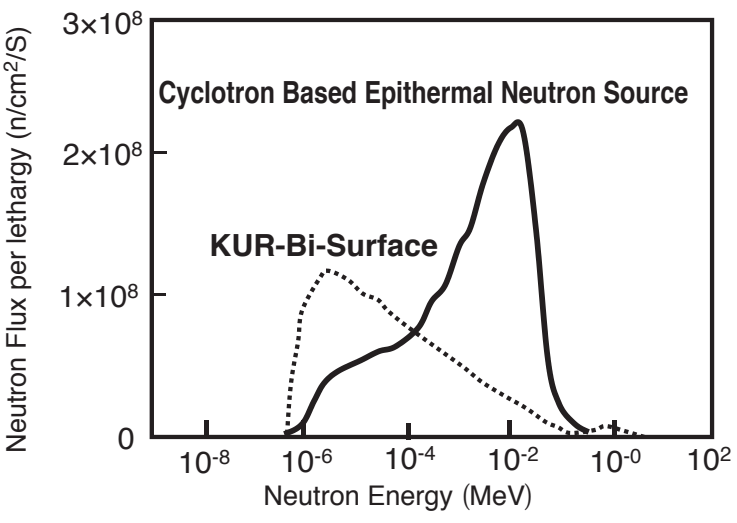

Fig. 4 Epithermal neutron energy distribution from the reactor (KUR) and an accerelerator. ${ }^{12}$

た ${ }^{12)}$. 一方, 筑波大学では線形陽子加速器を用い, 比較 的低い加速エネルギー $(8 \mathrm{MeV}$ ), 高電流(平均 $10 \mathrm{~mA}$ )の 条件を選定し ${ }^{13)}$, 茨城県東海村のいばらき中性子医療研 究センターに設置された

レーザー駆動もBNCTのための中性子として，コンパ クトな中性子源の候補一つとして応用が期待される。放 射線治療の場合，患部の詳細な位置や広がり等の確認後 立てられる綿密な治療計画の基で照射が実施される。特 に中性子の場合はほかの放射線と異なり，体内で複雑な 反応による熱中性子へのエネルギー変化や $\gamma$ 線の発生な ど単純には治療計画は決定できない。 また, 数回に分け て照射する $\gamma$ 線治療と異なり, 中性子照射は一回で完了 することが多いため, 放射線で影響を受けた周囲の健全 な細胞の治療中の回復は期待できない，そのため, 治療 計画立案にあたってはモンテカルロ法を基本としたシ ミュレーションで照射条件を決定されている ${ }^{14)}$. そのシ ミュレーションに必要な発生源での熱外中性子のエネル ギー分布と強度の正確なデータと通常1時間程度の照射 時間内の安定性と再現性が, 他の用途以上に厳しく要求 される。これらの要求を満足した十分な強度の熱外中性 子源のための研究開発が必要である.

\section{4. 中性子産業利用の現状と小型中性子源への期待}

理化学研究所における小型中性子の開発と産業界との 積極的な共同研究, 北海道大学加速器中性子源, 京都大 学の関西原子炬における特徵ある研究開発は, 中性子を 一部専門家による特殊な解析手段から, 沉用析解析装置 として認識されるようになってきている。しかし，X線 などと比較した場合, 中性子はそのビーム強度は低いた め本格的な構造解析や本質的解析のためには大型施設に 頼らざるを得ないことも否定できない，産業利用におい ては種々の課題の本質的解析と理解ばかりではなく, 現 実の生産工程や材料特性との関連づけのため, 迅速な分 析が必要になることが多い. そのため, 大型施設と小回 りの利く小型施設の適切な使い分けが必要である。この ような観点から, 早くから中性子の利用を積極的に研究 開発に取り入れてきている鉄鋼分野での取り組みから, 
小型施設の利用の可能性を，またJ-PARC等の大型施設 における産業利用の具体的成果から大型施設と小型施設 との相補利用の必要性について議論する。

\section{1 鉄鋼分野における中性子利用}

世界の鉄鋼生産量は中国を除いてほぼ横ばいである が, 我国の鉄鋼メーカからは着実な研究開発と品質管理 により高品質なオンリーワン商品が, 供給されてい

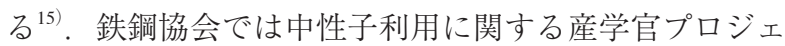
クト「中性子利用鉄鋼評価技術の基礎検討に係る研究」 （2006２008年度）をはじめ，「小型中性子源ブラッグ エッジイメージングによる結晶相体積分率の高精度卜モ グラフイ評価・分析・解析」(2018年度),「パルス中性子 を用いたミクロ組織の定量評価およびイメージング技術 の開発」(2017年度),「中性子線による高温オーステナイ 卜組織の動的微細組織変化のその場観察」(2016年度)な ど若手研究者への研究助成，さらに「新世代中性子源を 利用した鉄鋼元素機能分析」(2009～2012年度)や「小型中 性子源による鉄鋼組織解析法」(2014～2016年度)などの 研究会を通して中性子利用を積極的に取り入れ，多くの 成果を挙げている.

鉄にわずか $(0.8 \mathrm{wt} \%$ 以下 $)$ の炭素が固溶した鉄鋼には 低温相であるフェライトと高温相のオーステナイトが 存在する。高温で安定なオーステナイト相が冷却過程で フェライト相に変態する際に炭化物などのナノメート ルサイズの粒子を析 出させることにより，高強度かつ 加工性も確保された鉄鋼材料が製造されている ${ }^{15)}$. この ように，鉄鋼材料は複数の相で構成され，その相の割合 や大きさ組織などを 熱処理や加工などにより，最終製 品の特性が制御される。そのため, 原子レベルでの結晶 構造と欠陥, 数 $\mathrm{nm}$ ベルの析出物, 数 $\mu \mathrm{m}$ の結晶粒や 相構成といった組織の階層構造を総合的に観察し解析 する必要がある。構造解析の空間分解能の観点からは電 子線やX線が優れているが, それらは表面近傍あるいは 薄膜の情報に限られている。電子線は数十 $\mathrm{nm}$, 実験室 のX線では数十 $\mu \mathrm{m}$, 高エネルギーX線でもサブ $\mathrm{mm}$ 程度 であるのに対して，熱中性子はFig. 5 に示したように 数 $\mathrm{cm} の$ 厚さの試料の観察が可能である ${ }^{16)}$. 中性子観察 なしでX線や電子顕微鏡での観察のみでは, “木を見て

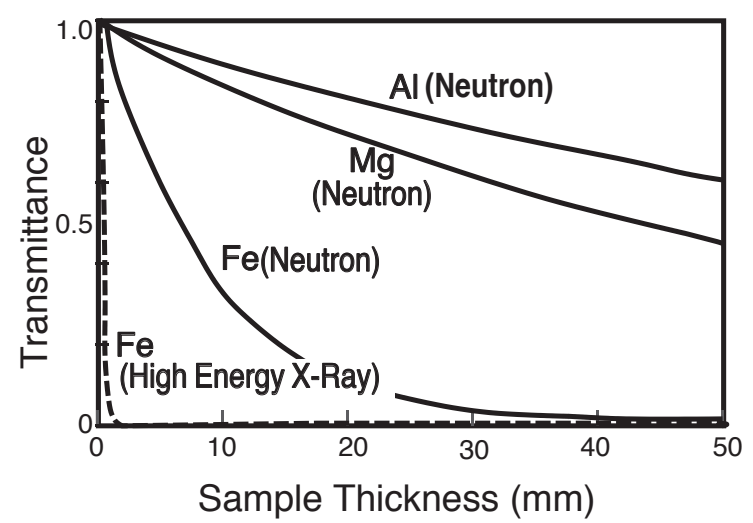

Fig. 5 Decay curve for High Energy X-ray and Neutron. ${ }^{16)}$
森を見ず”となってしまい, 生産工程の管理や商品の品 質や特性に間違った情報を提供してしまう危険を伴 $j^{16)}$. 鉄鋼材料の中性子を利用した解析では，加工や熱 処理による材料の残留応力 ${ }^{17)}$, 試料中の結晶方位分布を 解析手えられる極点図 ${ }^{18)}$, 塗膜下の鋼材の腐食挙動のイ メージング観察 ${ }^{19)}$ ，パルス中性子イメージング装置にお けるブラッグエッジ法による相分布, 残留応力分布およ び結晶粒形分布解析 ${ }^{20)}$, さらに小角散乱法による析出物 の大きさや形状分布の解析 ${ }^{21,22)}$ ，転位などの格子欠陥評 価 ${ }^{23)}$ な゙の成果が報告されている.

これらの成果のうち, 残留応力, イメージング, 小角 散乱は小型中性子源(理研-RANS等)で測定, 解析が可能 であることが確認されている。中性子小角散乱では自動 車産業や土木建築分野における革新的材料である高張力 鋼 (ハイテン $)^{24)}$ の開発に重要な情報が提供された ${ }^{22}$. フェライト相とオーステナイト相の微細組織により制御 されていた鉄鋼材料に, $\mathrm{Ti}(-\mathrm{Mo}) \mathrm{C}$ 㻭サイズの析出物 をその粒形や母相中での分散構造を巧妙な熱処理技術で 制御し, さらにその析出過程で実施される加工技術によ り, 複雑な形状への加工を実現したNANOハイテン®が 開発された ${ }^{15)}$. nmサイズの析出物はX線小角散乱や電子 顕微鏡観察でも解析であるが，材料全体の平均構造把握 のためには中性子による解析は不可欠であった。Ti添 加炭素鋼 $(0.045 \% \mathrm{C}-1.8 \% \mathrm{Mn}-0.2 \% \mathrm{Ti}-0.004 \% \mathrm{~N}-0.003 \% \mathrm{~S})$ の $1250^{\circ} \mathrm{C}$ 処理後の冷却過程中の一定温度での 5 時間の保 持温度の上昇 $\left(550^{\circ} \mathrm{C}-650^{\circ} \mathrm{C}\right)$ に伴い, 板状 $\mathrm{TiC}$ 析出物の 厚さは約 $1 \mathrm{~nm}$ か $2 \mathrm{~nm}$ に，大きさが $4 \mathrm{~nm}-8 \mathrm{~nm}$ に変化で することが中性子小角散乱で確認された ${ }^{24)}$ 。鋼材の引張 強度は析出物の大きさとFig. 6 に示したような相関関係 があることが確認され，より微細な析出物の実現による さらに高強度の1180 Pa級NANOハイテンのの開発につな がっている ${ }^{15)}$ 。この実験は実験用原子炉JRR-3の小角散 乱装置を用い $15 \mathrm{~mm} \times 15 \mathrm{~mm} \times 2 \mathrm{mmt}$ の試料に10 $\mathrm{mm}$ Фの

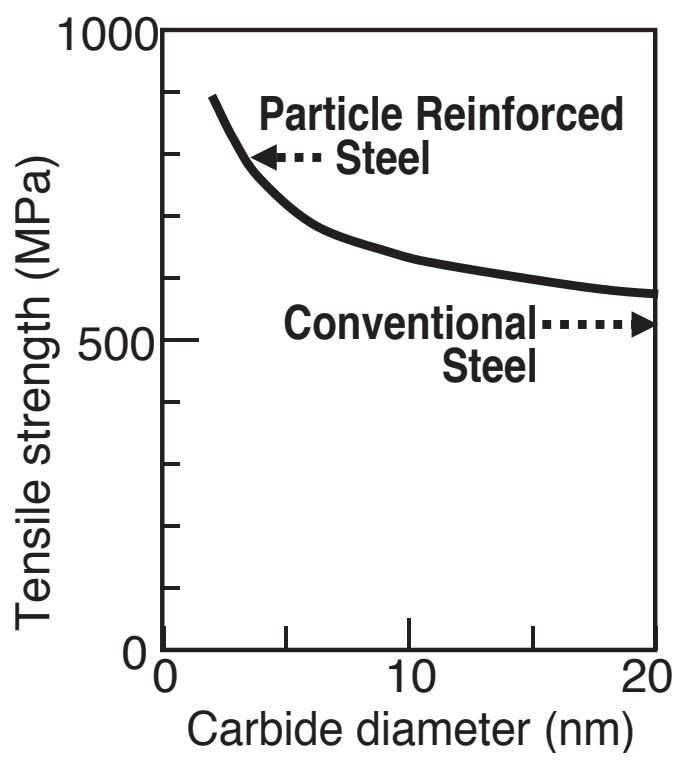

Fig. 6 Schematic diagram of a Relation between Carbide precipitates Size and Tensile Strength. ${ }^{22)}$ 
中性子ビームを用いて実施 ${ }^{22}$ されたが, 北海道大学の小 型中性子源を用いても6時間程度で将来的には1時間程度 で，同等の実験が可能であると試算されている ${ }^{25)}$.

鉄鋼材料では複雑な熱処理による相分離や析出の制御 により優れた特性を持つ材料が製造されている。このよ うな処理過程での構造や組織の変化や残留応力を時分割 ですることも試みられている ${ }^{26)}$ 。このような解析には 高強度パルス中性子源が必要である。低合金 $(2 \mathrm{Mn}-$ $0.2 \mathrm{C}$ ) 鋼の冷却過程での変態の様子を高エネルギー加速 器研究所の $5 \mathrm{~kW}$ のパルス中性子源ではステップ的な加 熱-冷却により 1 時間毎に得られた粉末回折プロファイル により解析された ${ }^{26)}$ が, $500 \mathrm{~kW}$ J-PARCのパルス中性 子源を用いれば1分毎の測定で十分なデータが得られる ことが確認されている ${ }^{26)}$. これらの結果は, 大型施設で の実験のための準備あるいは予備実験に小型中性子源の 活用が有効であることも示唆している.

\section{2 大型施設との連携利用}

J-PARCの中性子施設が2008年末から共用運転を実施 し, 当初は茨城県が建設運営を担当した茨城県材料構造 解析装置 (iMATERIA)が積極的に産業利用課題を受け入 れ，前節の鉄鋼分野や電池材料などで成果が得られた。 震災復興後から2016年にかけてエネルギー分析型中性子 イメージング装置(RADEN)などの他の装置の整備が進 められ，多くの産業利用課題が実施された．2012年度か ら運用を始めた共用ビームラインにおいても, 産業利用 課題が実施された。共用ビームラインには非弾性散乱, 準弾性散乱, 高圧下回折, 小角散乱, 単結晶解析, 反射 率，イメージングの装置が準備され，2012２016年度の 間に, Fig. 7 に示したように自動車や電池などのエネル ギー関連産業からの課題に加え, タイヤゴム, 樹脂, 化 粧品, 食品関連などの有機系素材に関連する課題が増加

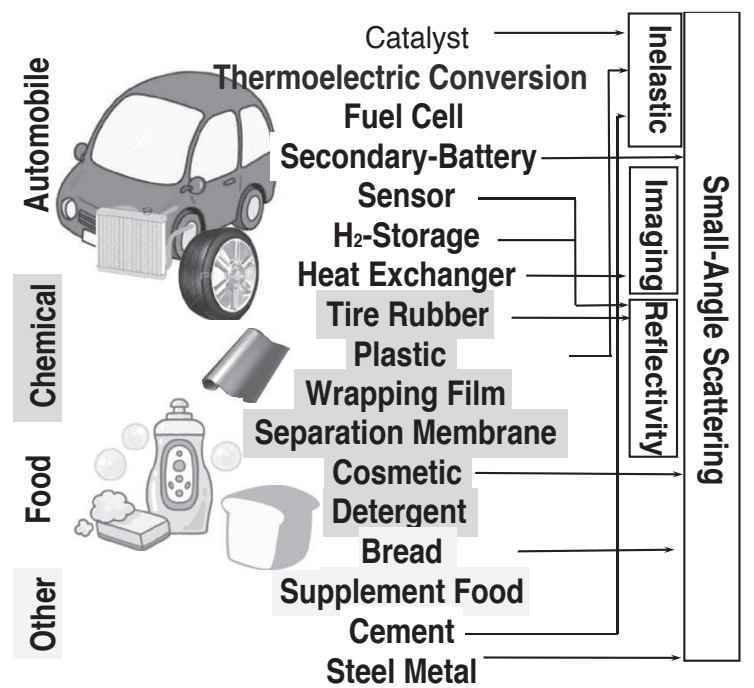

Fig. 7 Industrial Use of Neutron Public Beam Line at J-PARC.
の傾向を示している. nmスケールの構造に着目した小 角散乱の結果を踏まえた非弾性や準弾性散乱, 反射率測 定が実施されている例が多い.

住友ゴム工業株における低燃費タイヤの開発において は, Spring-8におけるX線小角散乱 ${ }^{27)}$ や型コンピュー ター「京」によるシミュレーション, J-PARCの中性子に よる小角散乱 ${ }^{27)}$, 準弾性散乱 ${ }^{28)}$, 反射率などの実験を有 効に活用し，大幅に燃費が改善された自動車用夕イヤが 開発された ${ }^{11,2}$. このような研究開発における解析や観 測の多くは大型施設の高強度中性子源により実現された ものが多い. しかし，その過程においてシミュレーショ ンとの比較検討の際や大型施設の有効な実験計画立案の ための小角散乱や反射率実験が機動的に実施可能な小型 中性子源の必要性が改めて認識されている.

\section{5. 結 言}

小型中性子源あるいはレーザー駆動中性子源独自の産 業, 医療分野への応用の可能性について展望した。 しか し, これらは“これまでのレーザー駆動中性子の予備実 験結果や他の中性子源の成果をもとに, さらに計測器や 中性子源としての挑戦的な研究開発が成功したら”とい う，未だ“たら〜れば”の期待の上では幅広い産業応用が 広がるであろうという希望的観測の域を出ていない。今 後, レーザー科学と中性子科学との連携ばかりではな く, ユーザである材料科学や産業界との連携の下に, 対 象を絞った装置の研究開発の開始が必要であろう。

\section{謝 辞}

本報告をまとめるにあたり，甲斐 哲也(日本原子力研 究機構), 大竹 淑惠 (理化学研究所), 鬼柳 善明 (名古屋 大学) 各氏からの情報と示唆助言は不可欠であった。こ こに謝意を表する。

\section{参考文献}

1) 大竹 淑惠, 山田 雅子, 竹谷篤, 須長 秀行, 中山 武典 : ISOTOPE NEWS 722 (2014) 8.

2）大竹 淑恵，須長 秀行：JACIC情報 110（2014）62.

3) 山田雅子, 大竹淑惠, 竹谷篤, 須長秀行, 山形豊, 若林 环巳，河野研二，中山武典：鉄と鋼 100 (2014) 429 .

4) K. Kaneko, T. Kamiyama, Y. Kiyanagi, T. Sakuma, and S. Ikeda: J. Phys. Chem, Solids 60 (1999) 1499.

5）甲斐哲也：Isotope News 727 (2014） 16.

6) K. Shibata, O. Iwamoto, T. Nakagawa, N. Iwamoto, A. Ichihara, S. Kunieda, S. Chiba, K. Furutaka, N. Otuka, T. Ohsawa, et al.: J. Nucl. Sci. Technol. 48 (2011) 1.

7) T. Kai, K. Hara, Y. Matsumoto, J. Parker, K. Hiroi, M. Segawa, T. Shinohara, H. Hayashida, S. Zhang, K. Oikawa, et al.: 7th Workshop of NEUtron WAVElength-dependent imaging (NEUWAVE-7) (Mito Japan, 2015) (Oral presentation).

8) J. Chadwick: Proc. Royal Society of Dmdon, A. 136 (1932) 692.

9) L. E. Farr, J. S. Robertson, and I. Stick: Proc. National Academy of Sciences of the USA 40 (1954) 1087.

10) K. Ishiwata, T. Ido, M. Kawamura, K. Kubota, M. Ichihashi, and Y.

\footnotetext{
†1住友ゴム工業(株) 他：Spring-8 ホームページ (2015); http://www.spring8.or.jp/ja/news_publications/press_release/2015/151112/

†2住友ゴム工業(株) 他：J-PARC ホームページ (2015); https://www.j-parc.jp/ja/topics/2015/Press151112.html
} 
Mishima: Int J. Rad. Appl. Instrum. B 18 (1991) 745.

11) T. Aihara, N. Morita, N. Kamitani, H. Kumada, K. Ono, J. Hiratsuka, and T. Harada: App. Radiationand Isotopes 88 (2014) 12.

12) 田中 浩基 : Radioisotopes 64 (2015) 29.

13) H. Kumada, A. Matsumur, H. Sakurai, T. Sakae, M. Yoshioka, H. Kobayashi, H. Matsumoto, Y. Kiyanagi, T. Shibata, H. Nakashima, et al.: Appl. Rad. Isotopes 88 (2014) 211.

14) 熊田 博明：Radioisotopes 64 (2015) 37.

15) 佐藤 馨，村上 㻟哉：NanotechJapan Bulletin 7 (2014) 1 .

16）友田陽：まてりあ 56 (2017) 14.

17) Y. Tomota, S. Daikuhara, S. Nagayama, M. Sugawara, N. Ozawa, Y. Adachi, S. Harjo, and S. Hattori: Metall. Mater. Trans. A 45 (2014) 6103.

18) T. Tomida, M. Wakita, M. Yasuyama, S. Sugaya, Y. Tomota, and S. C. Vogel: Acta Mater. 61 (2013) 2828.

19）山田 雅子, 大竹 淑恵, 竹谷篤, 須長 秀行, 山形豊, 若林 环已, 河野研二, 中山武典：鉄と鋼 100 (2014) 429.
20) Y. H. Su, K. Oikawa, S. Harjo, T. Shinohara, T. Kai, M. Harada, K. Hiroi, S. Zhang, J. D. Parker, H. Sato, et al.: Mater. Sci. Eng. A 675 (2016) 19.

21) Y. H. Su, S. Morooka, M. Ohnuma, J. Suzuki, and Y. Tomota: Metall. Mater. Trans. A 46 (2015) 1731.

22）安原久雄，佐藤 馨，田路勇樹，大沼 正人，鈴木 淳市， 友田陽：鉄と鋼 96 (2010) 545 .

23) S. Harjo, T. Kawasaki, W. Gong, I. Aizawa, Y. Tomota, and Z. Shi: CAMP-ISIJ (Current Advances in Materials and Processes-The Iron and Steel Institute of Japan) 28 (2015) 264.

24）船川 義正，藤田 毅，山田克美：JFE技報 30 (2012) 1 .

25) 大沼 正人, 佐藤 馨：精密工学会誌 79 (2013) 326

26）友田陽：まてりあ56 (2017) 70.

27) R. Mashita, H. Kishimoto, R. Inoue, and T. Kanaya: Polymer Journal 45 (2012) 57.

28) R. Mashita, R. Inoue, T. Tominaga, K. Shibata, H. Kishimoto, and T. Kanaya: Soft Matter 13 (2017) 7862. 